\title{
Isolation and Screening of Phosphate and Potassium Solubilizing Endophytic Bacteria in Maize (Zea mays L.)
}

\author{
Hilyatul Azizah ${ }^{1 *}$, Saptini M. Rahajeng ${ }^{2}$, Yoga D. Jatmiko ${ }^{3}$ \\ ${ }^{1}$ Master Program of Biology, Department of Biology, Faculty of Mathematics and Natural Sciences, University of \\ Brawijaya, Malang, Indonesia \\ 2 Indonesian Center of Agricultural Training (ICAT) Ketindan, Lawang, Malang, Indonesia \\ ${ }^{3}$ Department of Biology, Faculty of Mathematics and Natural Sciences, University of Brawijaya, Malang, Indonesia
}

\begin{abstract}
Maize (Zea mays L.) is a functional food source in Indonesia after rice and wheat. Increasing maize productivity can be done by developing a proper environment and nutritional availability during cultivation. The use of endophytic bacteria as biofertilizers is one prospective approach in reducing the synthetic fertilizers in the soil, and improving the absorption of macronutrients, such as nitrogen, phosphate, and potassium, as well. This study aimed to obtain phosphate solubilizing bacteria (PSB) and potassium solubilizing bacteria (KSB). The samples of maize leaves, stems, and roots were isolated using a serial dilution method and selected on a Pikovskaya (PKV) and Aleksandrov medium. A total of 10 PSB isolates were obtained from PKV selective agar media. The highest density was obtained in the root $\left(8.3 \times 10^{5}\right.$ CFU. $\left.\mathrm{mL}^{-1}\right)$, stems $\left(5.7 \times 10^{5} \mathrm{CFU} . \mathrm{mL}^{-1}\right)$, and leaves $\left(4.6 \times 10^{5} \mathrm{CFU} . \mathrm{mL}^{-1}\right)$, respectively. Meanwhile, the diversity index of the PSB ranges from 0.7 to 0.78 , indicates that the diversity index is high. Four isolates from PSB (AP1.3, AP3.1, AP1.2, and AP1.4) were selected as KSB because of the clear zone formed in Aleksandrov's medium. The highest production of phosphate and potassium was obtained by AP1.3 with value $12.11 \mu \mathrm{g} \cdot \mathrm{mL}^{-1}$ and $8.38 \mu \mathrm{g} \cdot \mathrm{mL}^{-1}$ at $72 \mathrm{~h}$ and $15 \mathrm{~d}$, respectively. Therefore, these isolates potential to be used as an organic fertilizer (biofertilizers).
\end{abstract}

Keywords: Biofertilizer, endophytic bacteria, phosphate, potassium.

\section{INTRODUCTION}

Maize is the third staple food source after rice and wheat. According to the Trade Analysis and Development Agency (Badan Pengkajian dan Pengembangan Perdagangan - BPPP), Ministry of Trade, Republic of Indonesia the export value of maize in Indonesia in the 2010-2015 periods increased by $4.42 \%$. Future agriculture is characterized by sustainable production processes that are able to remain productive without causing environmental impact [1].

Decreasing soil fertility due to depletion of soil organic matter and environmental damage requires a sustainable, agricultural system, namely organic farming. Through organic farming, it is expected, that it can maintain soil fertility, both physically, biologically, and chemically as in natural ecosystems by applying organic fertilizers, one of which is by utilizing the endophytic bacteria as agents of providing soil organic matter (biological fertilizers).

Biofertilizer is a fertilizer that contains live microorganisms. If these microorganisms are applied to seeds, plant surfaces, or soil, they promote their growth by increasing the supply of

\footnotetext{
* Correspondence address:

Hilyatul Azizah

Email : hilyaalawi@gmail.com

Address : Dept. Biology, University of Brawijaya, Veteran Malang, 65145
}

essential nutrients [2]. One of the important macronutrients is phosphorus and potassium which are required by plants to grow and develop. However, these efforts become efficient for plants because $P$ is fixed by $\mathrm{Al}$ and $\mathrm{Fe}$ elements in acidic soils, while in alkaline soils, $\mathrm{P}$ will be fixed with $\mathrm{Ca}$ so that it was difficult for plants to utilize $[3,4]$. Meanwhile, the element of $K$ is easily washed by water in the soil $[5,6]$. The ineffective usage of $P$ and $K$ fertilizers can be overcome by utilizing phosphate solubilizing bacteria (PSB) and potassium solubilizing bacteria (KSB) from plant tissues. Therefore, this study was to obtain phosphate solubilizing endophytic bacteria and potassium solubilizing bacteria from roots, stems, and leaves in maize (Zea mays L.).

\section{MATERIAL AND METHOD Sample Collection}

The samples of roots, stems, and leaves of maize plants aged 45-60 DAP were taken from the maize plant conservation area of Indonesian Center of Agricultural Training (ICAT) Ketindan Lawang, Malang, Indonesia with the coordinates of the location (S 07049'53.2") (E 112041'24.5") and an altitude of 548 masl. Composite sampling was carried out at five points with three replicates. 


\section{Isolation of Phosphate Solubilizing Bacteria}

Surface sterilization was carried out by the method from Zhang et al., [7] with minor modification. Maize samples were cut $(1-2 \mathrm{~cm})$, a total of 15 grams of sample was washed with running water until clean, soaked in $70 \%$ ethanol for $2 \mathrm{~min}$. Then soaked in $2 \% \mathrm{NaOCl}$ solution for 3 $\mathrm{min}$, and then rinsed with sterile distilled water four times (one minute each time). The sample $(10 \mathrm{~g})$ was homogenized with a sterile mortar and dissolved in $90 \mathrm{~mL}$ of $0.85 \% \mathrm{NaCl}$. Serial dilutions up to $10^{-6}$ was carried out, $0.1 \mathrm{~mL}$ of a sample from each dilution was inoculated on Pikovskaya agar (10 g glucose, $5 \mathrm{~g} \mathrm{Ca}_{3}\left(\mathrm{PO}_{4}\right)_{2}, 0.5 \mathrm{~g}\left(\mathrm{NH}_{4}\right)_{2} \mathrm{SO}_{4}$, $0.2 \mathrm{~g} \mathrm{KCl}, 0.1 \mathrm{~g} \mathrm{MgSO}_{4}$. $7 \mathrm{H}_{2} \mathrm{O}, 0.5 \mathrm{~g}$ yeast extract, $25 \mathrm{mg} \mathrm{MnSO}_{4}, 25 \mathrm{mg} \mathrm{FeSO}_{4}$, and $20 \mathrm{~g}$ bacto agar in $1 \mathrm{~L}$ aquadest, $\mathrm{pH} \pm 7$ ) incubated for $3 \mathrm{~d}$ at $28^{\circ} \mathrm{C}$ [5]. Colonies that produce a clear-zone on Pikovskaya's agar medium were characterized to determine their diversity index.

The bacterial communities' diversity was determined by the Simpson diversity index [8]. Bacterial diversity is calculated from the number of bacterial isolates obtained.

$$
D=1-\sum_{\mathrm{i}=1}^{s} \frac{n_{\mathrm{i}}\left(n_{\mathrm{i}}-1\right)}{N(N-1)}
$$

\section{Description:}

$D=$ Simpson diversity index

$\mathrm{ni}=$ number of individuals of type $\mathrm{i}$

$\mathrm{N}=$ total number of individuals

$s=$ total number of species in the community

The PSB were selected on the basis of morphological parameters size, shape, colour, margin, and texture. All isolates were purified by quadrant streaking on nutrient agar slant for further testing.

\section{Quantitative Assay of PSB}

The ability of the isolated bacteria to solubilize phosphate was tested with a minor modification method from Lynn et al. [9]. One loop of the bacterial isolate was inoculated on Pikovskaya broth, incubated in a shaker at 120 $\mathrm{rpm}, 30^{\circ} \mathrm{C}$, for $48 \mathrm{~h}$. The suspension of bacterial culture $(5 \mathrm{~mL})$ with optical density 0.5 was inoculated in $45 \mathrm{~mL}$ of Pikovskaya broth. The cultures were incubated in a shaker at $120 \mathrm{rpm}$, $30^{\circ} \mathrm{C}$ for $96 \mathrm{~h}$. The culture suspension $(2 \mathrm{~mL})$ was taken at incubation times of $0,24,48,72$, and 96 $h$ and centrifuged at $10.000 \mathrm{rpm}$ for 20 minutes.

The supernatant $(1 \mathrm{~mL})$ was added to $10 \mathrm{~mL}$ of chloromolibdic solution and $0.1 \mathrm{~mL}$ of chlorostannous acid, then added with sterile distilled water to a volume of $50 \mathrm{~mL}$. The suspension was homogenated and incubated at room temperature for 10 minutes. After forming a blue color, the absorbance of the sample was measured at $\lambda=660 \mathrm{~nm}$. The concentration of solubilize phosphate produced by each isolate was calculated based on the standard phosphate curve equation.

\section{Potassium Solubilization Efficiency of PSB}

The qualitative test was carried out by using the spot test method on Aleksandrov agar $(5 \mathrm{~g}$ $\mathrm{C}_{6} \mathrm{H}_{12} \mathrm{O}_{6}, 0.5 \mathrm{~g} \mathrm{MgSO}_{4} .7 \mathrm{H}_{2} \mathrm{O}, 0.1 \mathrm{~g} \mathrm{CaCO}_{3}, 0.006 \mathrm{~g}$ $\mathrm{FeCl}_{3}, 2 \mathrm{~g} \mathrm{Ca}_{3}\left(\mathrm{PO}_{4}\right)_{2}, 3 \mathrm{~g} \mathrm{KAISi}{ }_{3} \mathrm{O}$ (K-feldspar), $20 \mathrm{~g}$ agar in $1 \mathrm{~L}$ of distilled water, $\mathrm{pH} \pm 7$ ). All the selected PSB strains were taken using a sterile toothpick, then, inoculated on Aleksandrov agar medium for $72 \mathrm{~h}$ at room temperature. After incubation, the diameter of the potassium solubilizing zone around the bacterial colonies was measured [5].

\section{Quantitative Assay of KSB}

The quantitative test of KSB was carried out based on a modified method $[9,4,24]$. Preparation of starter cultures was carried out as conducted in P solubilization. The culture $(5 \mathrm{~mL})$ was inoculated into $45 \mathrm{~mL}$ of Aleksandrov broth medium and incubated in a shaker for $15 \mathrm{~d}$ at $28^{\circ}$ C. Every $5 \mathrm{~d}, 6 \mathrm{~mL}$ of the bacterial culture was centrifuged at $10,600 \mathrm{rpm}, 28^{\circ} \mathrm{C}$ for 10 minutes. The supernatant was measured by using a Flame photometer. Standard curves were created using the $\mathrm{KCl}$ concentration.

\section{Data analysis}

The qualitative and quantitative data of phosphate and potassium solubilizing bacteria was analyzed based on a Two-Way ANOVA followed by a Tukey test using SPSS 16 .

\section{RESULT AND DISCUSSION Diversity and Density of Phosphate Solubilizing Bacteria}

A total of 10 endophytic bacterial isolates have been isolated from samples of roots, stems, and leaves of maize (Zea mays L.) on Pikovskaya agar (Fig. 1). The phosphate solubilizing bacteria density in the samples of roots, stems, and leaves of maize plants were $8.3 \times 10^{5} \mathrm{CFU}^{-1}, 5.7 \times 10^{5}$ CFU.g ${ }^{-1}$, and $4.6 \times 10^{5} \mathrm{CFU}^{-1}{ }^{-1}$, respectively. The density calculation results showed the highest density was found in the root sample, followed by the stem and leaf. It is because roots are one of the main pathways for bacteria to enter plant tissues, and roots can easily absorb nutrients in the soil [10]. 

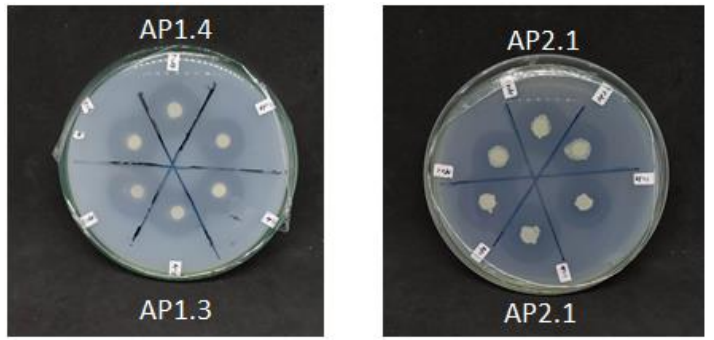

Figure 1. The clear zone formed on Pikovskaya selective media by PSB isolates with three replications.

The results of the Simpson diversity index calculation showed that, in both the solubilizing phosphate and potassium samples of roots, stems and leaves did not show any significant differences, with values ranging from 0.7-0.78. According to Ludwig and Reynolds [11], the closer to number one, the community between individuals is increasingly complex. Endophytic bacteria are bacteria that colonize plant tissue and are not parasitic during their life cycle. Several factors can influence the growth and development of endophytic bacteria, such as types of plants, environmental conditions (soil), community structure, and agricultural practices which also affect the colonization of endophytes in them [12].

\section{Quantitative Estimation of PSB}

Phosphate solubilizing bacteria (PSB) are soil bacteria that can dissolve phosphate so that it can be absorbed by plants. In addition to increasing phosphate in the soil, it can be improving plant root growth and increasing nutrient uptake. PSB is able to secrete organic acids so that it will reduce soil $\mathrm{pH}$ [13].

The results of the quantitative estimation of phosphate solubilizing endophytic bacteria showed that the isolate AP1.3 was able to dissolve the highest $P$ at the $48 \mathrm{~h}$, amounting to $10.34 \mu \mathrm{g} \cdot \mathrm{mL}^{-1}$ and an increase at the $72 \mathrm{~h}$ to $12.07 \mu \mathrm{g} \cdot \mathrm{mL}^{-1}$. Meanwhile, the $96 \mathrm{~h}$ decreased by $8.97 \mu \mathrm{g} \cdot \mathrm{mL}^{-1}$ (Fig. 2). Isolate BP1.3 dissolved the second-highest phosphate at $10.53 \mu \mathrm{g} \cdot \mathrm{mL}^{-1}$ at 72 $\mathrm{h}$ and increased in concentration by $0.56 \mu \mathrm{g} \cdot \mathrm{mL}^{-1}$ at $96 \mathrm{~h}$. DP1.2, DP1.4, and DP2.2 from the 0 to 96 $\mathrm{h}$ incubations time did not show any significant increase in phosphate production with an average production value of $2.48-5.61 \mu \mathrm{g} \cdot \mathrm{mL}^{-1}$. It is because some PSB isolates require a longer incubation time than other isolates.

The previous study showed that the quantitative results of the PSB PEEHME5 isolate could dissolve $99 \mu \mathrm{g} \cdot \mathrm{mL}^{-1}$ of phosphate within $7 \mathrm{~d}$ of incubation [12]. Terribacillus saccharophilus strain 002-048 was able to solubilize the highest phosphate of $0.29 \mu \mathrm{g} \cdot \mathrm{mL}^{-1}$ at $48 \mathrm{~h}$ [14]. The difference in the ability to solubilize the phosphate is influenced by different types of bacteria. In addition, it is also because the gene expression of each isolate is different in secreting organic acids [15].

PSB is able to utilize phosphate sources in liquid media containing $\mathrm{Ca}_{3}\left(\mathrm{PO}_{4}\right)_{2}$ as a source of insoluble $P$. The phosphate dissolution mechanism in the liquid media occurs due to the release of insoluble $P$ into soluble. Previous studies stated that several bacterial genera have been reported as PSB, namely Azotobacter, Burkholderia, Citrobacter, Enterobacter, Pantoea, and Pseudomonas [5,6].

Phosphates play a role in the process of decomposition of carbohydrates, transferring energy, forming nucleoproteins, root growth, accelerating maturity, producing fruit and seeds. Phosphorus plays an indispensable role as a universal fuel for all biochemical activities in the living cells $[16,28]$. The use of biological fertilizers (biofertilizers) in agricultural land is still limited by farmers in Indonesia. Agricultural Census of the Central Statistics Agency (BPS) in 2013 reported that $86.41 \%$ of farmers used inorganic fertilizers. Meanwhile, the use of balanced fertilizers (organic and inorganic) is only $13.5 \%$ and organic $0.07 \%$.

\section{Qualitative Estimation of KSB}

The qualitative results of potassium solubilizing showed four PSB isolates were capable of producing clear zones on Aleksandrov media within $72 \mathrm{~h}$ (Fig. 3). The clear zone formed on selective media is due to the production of polysaccharides or enzyme activity [17].

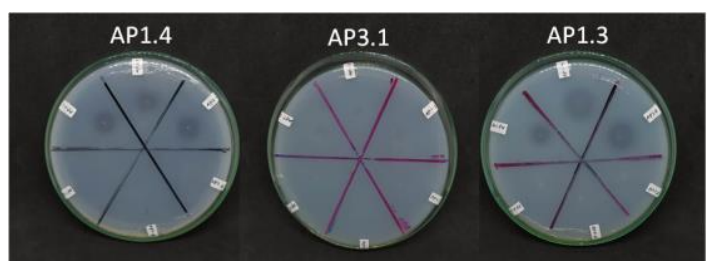

Figure 3. The clear zone formed on Aleksandrov selective media by PSB isolates with three replications.

The large clear zone formed on the media is not always caused by the size of a bacterial colony. In addition, the clear zone in the agar medium cannot represent the total concentration of solubilize phosphate or potassium. Bacillus sp. KF668 isolates could show clear zones at an incubation time of 48-96 h [12]. AKSB12, AKSB16, AKSB20, and AKSB24 isolates showed clear zones at $72 \mathrm{~h}$ [18]. 


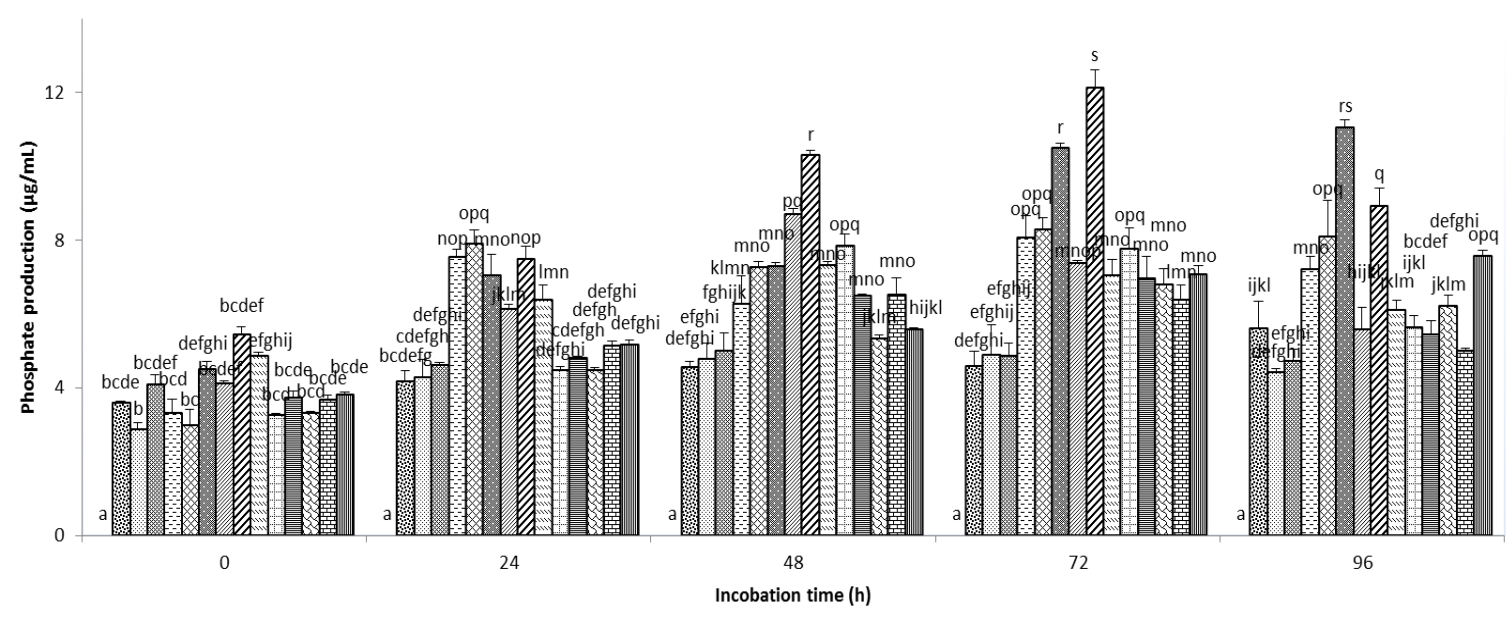

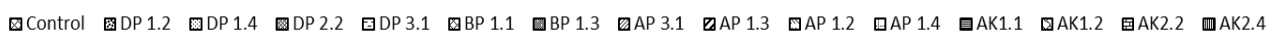

Figure 2. The quantitative test results of the phosphate solubilizing bacterial isolates at various incubation times. Data were expressed as mean \pm standard deviation of the three replications and the notations on this histogram indicate differences between treatments $(p<0.05)$.

\section{The Ability of Phosphate Solubilizing Bacteria to Solubilize Potassium}

Potassium is a macronutrient essential for plant growth. Potassium is needed in plants for metabolisms such as cell synthesis, enzyme production activities, protein, cellulose, and vitamins. Also, potassium can increase plant resistance to abiotic and biotic stress [26]. Potassium (K) also plays a role in regulating the transport of water and nutrients through the xylem. A sufficient amount of potassium guarantees plant vigor and stimulates root growth and strengthens stems, which means increasing plant resistance to pathogenic fungal attacks [27].

The results of the quantitative estimation of potassium solubilizing endophytic bacteria (Fig. 4.) showed that the AP1.3 can dissolve the highest potassium at the incubation time 10 days $7.68 \mu \mathrm{g} \cdot \mathrm{mL}^{-1}$ and has increased to $8.38 \mu \mathrm{g} \cdot \mathrm{mL}^{-1}$ at 15 days. On the $15^{\text {th }}$ day, the concentration of all isolates showed optimal results. Bacillus licheniformis and Pseudomonas azotoformans which were isolated from the soil of rice plants, using two potassium solubilizing bacteria, could increase the availability of potassium in the soil by $7.22 \mu \mathrm{g} \cdot \mathrm{mL}^{-1}$ and $6.03 \mu \mathrm{g} \cdot \mathrm{mL}^{-1}$ under optimal conditions.

In the qualitative test, the AP3.1 isolate showed the smallest clear zone. However, the quantitative test obtained the highest concentration values from day 5 to 15 (6.27, 7.47 , and $8.40 \mu \mathrm{g} . \mathrm{mL}^{-1}$, respectively). Moreover, a previous study isolated two bacterial strains from
Tianmu mountain regions which had excellent potassium solubilizing $B$. mucilagenosus for the decomposition of silicate in liquid culture [22]. Similarly, Adeleke [23] has reported the ability of ectomycorrhizal fungi in the mobilization of $P$ and $\mathrm{K}$ sources from insoluble.

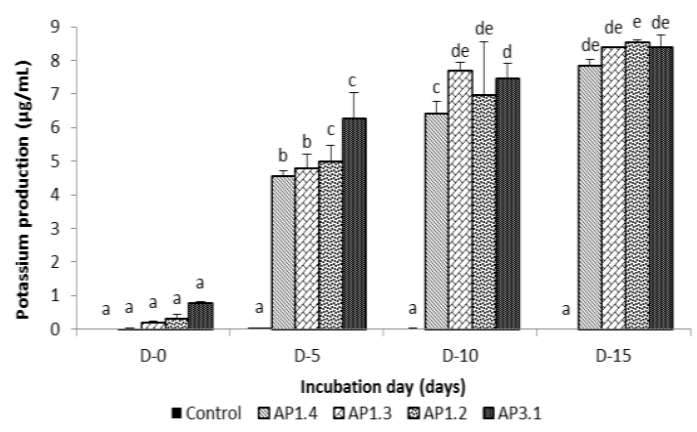

Figure 4. Quantitative test results of phosphate solubilizing bacteria in producing potassium. The different notations on this histogram indicate differences between treatments $(p$ $<0.05)$.

The efficient KSB strains were identified as Pseudomonas spp., Bacillus spp., and Burkholderia spp. by following various polyphasic taxonomic approaches. KSB strains preferred acidic to a neutral range of $\mathrm{pH}$, temperature, and other nutritional factors which were recorded as $\mathrm{pH} 7.0,25^{\circ} \mathrm{C}$, and $6 \%$ of $\mathrm{NaCl}$ concentration [24]. Several genera of potassium solubilizing bacteria (KSB) are Azospirillum, Agrobacterium, Bacillus, Enterobacter, Erwinia, Flavobacterium, Micrococcus, Pseudomonas, Rhizobium, and Serratia [20,21,25]. The mechanism of solubilizing potassium and insoluble potassium 
minerals such as mica, illite, and ortholox is by secreting organic acids such as (citric, oxalic, tartaric, succinic, and $\alpha$-ketoglucanic acids) by potassium solubilizing bacteria which directly dissolve $\mathrm{K}$ rock or chelate silicate ions to bring $\mathrm{K}$ into the dissolved form. In addition, $K$ dissolving occurs due to the formation of complexes between organic acids secreted by bacteria and metal ions that bind to $\mathrm{K}$ minerals such as $\mathrm{Fe}^{2+}$, $\mathrm{Al}^{3+}$, and $\mathrm{Ca}^{2+}[4,6]$. One of the most common signs of potassium deficiency is chlorosis of the leaf surface[24].

\section{CONCLUSION}

In this study, the AP1.3 isolate was the best as a phosphate and potassium solubilizing endophytic bacteria, which could be used as a biofertilizer. Then, the molecular identification and application of AP1.3 in plants are necessary to determine its ability to provide nutrients for plants.

\section{REFERENCES}

[1] Arifin, Z., A. Krismawati. 2008. Organic farming towards sustainable agriculture, $1^{\text {st }}$ Ed. Bayumedia Publishing. Malang.

[2] Rahmah, A., M. Izzati., S. Parman. 2014. The effect of liquid organic fertilizer made from chicory (Brassica chinensis L.) waste on the growth of sweet corn plants (Zea mays L. Var. Saccharata). Bulletin of Anatomy and Physiology. 22(1). 65-71.

[3] Asih, P.R., M. Suharman, Giyanto. 2017. Isolation of rhizobacteria and the effect of its application with N-P fertilizer on seed quality and seedling growth of maize. Jurnal Agronomi Indonesia. 45(3). 255-262.

[4] Bakhshandeh, E., H. Pirdashti, K.S. Lendeh, 2017. Phosphate and potassium-solubilizing bacteria effect on the growth of rice. Ecol. Eng. (103). 164-169.

[5] Mursyida, E., N.R. Mubarik, A. Tjahjoleksono. 2015. Selection and identification of phosphate-potassium solubilizing bacteria from the area around the limestone mining in Cirebon Quarry. Res. J. Microbiol. 10(6). 270-279.

[6] Meena, V.S., B.R. Marya, J.P. Verma, S.M. Ram. 2016. Potassium solubilizing microorganisms for sustinable agriculture. Springer eBook. India.

[7] Zhang, X., Y. Zhou, Y. Li, X. Fu, Q. Wang. 2017. Screening and characterization of endophytic Bacillus for biocontrol of grapevine downy mildew. Crop Prot. 96. 173-179.
[8] Setia, I.N., Suharjono. 2015. Diversity and potential test of chitinolytic bacteria from shrimp waste. Biotropika. 3(2). 95-98.

[9] Lynn, T.M., H.S. Win, E.P. Kyaw, Z.K. Latt, S.S. Yu. 2013. Characterization of phosphate solubilizing and potassium decomposing strains and study on their effets on tomato cultivation. Int. J. Innov. Appl. Stud. 3(4). 959-966.

[10] Parmar, P., S.S. Sindhu. 2013. Potassium solubilization by rhizosphere bacteria: influence of nutritional and environmental conditions. J. Microbiol. Res. 3(1). 25-31.

[11] Ludwig, J.A., J.F. Reynolds. 1988. Statistical ecology a primer on methods and computing. Wiley-Interscience Pub. New York.

[12] Marag, P.S., A. Suman. 2018. Growth stage and tissue specific colonization of endophytic bacteria having plant growth promoting traits in hybrid and composite maize (Zea mays L.). Microbiol. Res. 214. 101-113.

[13] Marista, E., S. Khotimah, R. Linda. 2013. Phosphate solubilizing bacteria isolated from three types of rhizosphere soil of the Nipah banana plant (Musa paradisiaca var. Nipah) in the City of Singkawang. J. Protobiont. 2(2). 93-101.

[14] Mohanty, S.R., G. Dubey, B. Kollah. 2017. Endophytes of Jatropha curcas promote growth of maize. Rhizosphere. (3). 20-28.

[15] Sashidhar, B., A.R. Podile. 2010. Mineral phosphate solubilization by rhizosphere bacteria and scope for manipulation of the direct oxidation pathway involving glucose dehydrogenase. J. Appl. Microbiol. 109(1). 1-12.

[16] Hardjowigeno, S. 1992. Geology. Peatlands: potential for agriculture and environmental aspects. ICRAF. Mediyatama Sarana Perkasa. Jakarta.

[17] Pande, A., P. Pandey, S. Mehra, M. Singh, S. Kaushik. 2017. Phenotypic and genotypic characterization of phosphate solubilizing bacteria and their efficiency on the growth of maize. J. Genet. Eng. Biotechnol. 15. 379391.

[18] Rajawat, M.V.S., S. Singh, S.P. Tyagi, A.K. Saxena. 2016. A modified plate assay for rapid screening of potassium solubilizing bacteria. Pedosphere. 26(5). 768-773.

[19] Chen, Y.P., P.D. Rekha, A.B. Arun, F.T. Shen, W.A. Lai, C.C. Young. 2006. Phosphate solubilizing bacteria from subtropical soil 
and their tricalcium phosphate solubilizing abilities. Appl. Soil. Ecol. (34). 33-41.

[20] Walpola, B.C., M.H. Yoon. In vitro solubilization of inorganic phosphates by phosphate solubilizing microorganisms. Afr. J. Microbiol. Res. (27). 3534-3541.

[21] Don, N.T., C.N. Diep. 2014. Isolation, characterization and identification of phosphate and potassium solubilizing bacteria from weathered materials of Granite Rock Mountain, that Son, an Giang Province, Vietnam. Am. J. Life Sci. 2(5). 282291

[22] Xiufang, H., C. Jishuang, G. Jiangfeng. 2006. Two phosphate and potassium solubilizing bacteria isolated from Tianmu Mountain, Zhejiang, China. W. J. Microbiol. Biotechnol. 22. 983.990.

[23] Adeleke, R.A., T.E. Cloete, A. Bertr, D.P. Khasa. 2010. Mobilization of potassium and phosphorus from iron ore by ectomycorrhizal fungi. World J. Microbiol. Biotechnol. 26. 190-195.

[24] Bagyalakshmi, B., P. Ponmurugan, A. Balamurugan. $2017 . \quad$ Potassium solubilization, plant growth promoting substances by potassium solubilizing bacteria (KSB) from southern Indian Tea plantation soil. Biocatal. Agric. Biotechnol. 12. 116-124.

[25] Verma, P., A.N. Yadav, K.S. Khannam, N. Panjiar, S. Kumar, A.K. Saxena, A. Suman, 2015. Assessment of genetic diversity and plant growth promoting attributes of psychrotolerant bacteria allied with wheat (Triticum aestivum) from the northern hills zone of India. Ann. Microbiol. 65. 18851899.

[26] Bashir, Z., M.Y. Zargar, M. Husain, F.A. Mohiddin, S. Kousar, A. Ahmad, J.P. Rathore. Potassium solubilizing microorganisms: mechanism and diversity. Int. J. Pure App. Biosci. 5(5). 653-660.

[27] Zhang, C., F. Kong. 2014. Isolation and identification of potassium-solubilizing bacteria from tobacco rhizospheric soil and their effect on tobacco plants. Appl. Soil Ecol. 82. 18-25.

[28] Viruel, E., L.E. Erazzú, L. Martínez-Calsina, M.A. Ferrero, M.E. Lucca, F. Siñeriz. 2014. Inoculation of maize with phosphate solubilizing bacteria: effect on plant growth and yield. J. Soil Sci. Plant Nutr. 14(4). 819831. 